\title{
A COMPARATIVE STUDY OF EXTROVERTED AND INTROVERTED STUDENTS' SPEAKING ACHIEVEMENT AT ENGLISH DEPARTMENT OF HALU OLEO UNIVERSITY
}

\author{
NURZANI \\ English Education Department Faculty of \\ Teacher Training and Education Halu Oleo \\ University
}

ABSTRACT

This study aimed to investigate whether there was a significant difference between extroverted and introverted students in terms of speaking achievement at speaking I class of English Education Department in Halu Oleo University academic year 2016/2017. The design of this study was quantitative comparative study. The population of this study was the entire speaking I class in English Department of Halu Oleo University in academic year 2016/2017 which consisted of two classes in total of 112 students. The sample of this study was chosen randomly of all the population by using Questionnaire of Eysenk Personality Inventory. The instruments of the study were questionnaire and final score of speaking 1 subject. In analyzing the data of the study, the researcher used Independent sample T-test in SPSS 16.0 for windows. In this study, the Independent Sample T-test was showed the value of Sig.(2-tailed) = 0.502 with $\alpha=0.05, \mathrm{H}_{0}$ was accepted and $\mathrm{H}_{1}$ was rejected. It is because of sig. (2-tailed) value is higher than $\alpha$ value. The result of this study showed that there was no significant difference between extroverted and introverted students' speaking achievement at speaking I class of English Education Department in Halu Oleo University academic year 2016/2017. This study showed that the students' personality, either extroverted or introverted did not give significant difference on the achievement of their speaking

KEYWORDS: Extroversion, Introversion, and Speaking Achievement 


\section{INTRODUCTION}

Speaking is a skill which is used for communicating with speech. Speaking skill is the art of communications and one of four productiveskills that must be mastered in learning foreign language. Good speaking skill is the act of generating words that can be understood by listeners. Moreover, speaking means interaction between two or more people in changing ideas and arguing something related to the human lives and movement of the world.

The tendency to prioritize the mastery of speaking is reflected in the tendency of society to make speaking skill as a measure of one's mastery of English. However, English as foreign language (EFL) learners still face many speaking difficulties, although they mastered other skills in English. The mastery of speaking skill in English is a priority for many second-language or foreign-language learners. Consequently, learners often evaluate a successful in language learning as well as the effectiveness of their English course on the basis of how much they feel they have improved in their spoken language proficiency (Richard, 2008).

There are some factors which influence speaking ability. One of them is personality. A number of personality characteristics have been proposed as likely to affect second language learning. Extroversion is one of them. Extrovert Personality is social, practical, appear affectionate, good conversationalists, active and lively. Contrary to extrovert, introvert personality is idealistic, less social, talk less and brood about the future. Difference in terms of sociability is then affects to speaking ability. In the EFL context, (Busch, 2006) investigated the relationship between the extroversion-introversion 
tendencies of Japanese students and their proficiency in English as a Foreign Language (EFL). The results showed that extraversion had a significant negative correlation with pronunciation, a subcomponent of the oral interview test. In addition, introverts tended to gain higher scores on the reading and grammar components of the standardized English test.

This study is conducted due to the findings from ESL/EFL studies that showed there is a correlation between extroversion/introversion personality and speaking styles. This study was conducted with the EFL students of speaking I class of English Education Department of Halu Oleo University in Academic year 2016/2017. They come from various regions and were graduated from different senior high school, so that they have different personality also different ability in English especially in Speaking.

\section{RESEARCH QUESTIONS}

In this study, the researcher formulated the problem as follows:

1. What is the extroverted students' speaking achievement at speaking I class of English Education Department in Halu Oleo University academic year 2016/2017?

2. What is the introverted students' speaking achievement at speaking I class of English Education Department in Halu Oleo University academic year 2016/2017?

3. Is there any significant difference between extroverted and introverted students in terms of speaking achievement at speaking I class of English Education Department in Halu Oleo University academic year 2016/2017? 


\section{REVIEW OF LITERATURE}

\section{Personality Trait}

Personality is usually discussed in terms of what makes a person different from others, what makes it unique compared to the others. This aspect of personality is called "individual differences. The Collins Cobuild Dictionary defines personality as one "s "whole character and nature." That is, personality refers to individual differences in characteristic patterns of thinking, feeling, and behaving (Dornyei, 2005). Traits, generally refers to a consistent style of emotion or behavior that a person displays across a variety of situations (Cervone \& Pervin, 2010). In other words, it is not necessarily immediately visible, but requires the observation of certain behaviors that are conducted consistently. Therefore, traits have strong links with behavior.

\section{Extroversion}

Extroversion is personality that is characterized by sociability, talkativeness, assertiveness, and excitability. Extroversion people tend to like the crowd, in this case like to mingle with others to socialize. Sharp (1987) said that extraverted thinking is conditioned by objective data transmitted by sense perceptions. In order to make a judgment, extraverted thinking fastens on the criteria supplied by external conditions, that is, those that have been transmitted through tradition and education. Extraverted thinking types are captivated by the object, as though without it they could not exist.

In addition, Jung in Sharp (1987:13) pointed out that "extraversion is normally characterized by an outgoing, candid, and accommodating nature that adapts easily to a given situation, quickly 
forms attachments, and, setting aside any possible misgivings, will often venture forth with careless confidence into unknown situations.". In other words, extraversion is easy to adjust in particular situations, easy to get along with new people around them, and have a good confidence to socialize with others.

\section{Introversion}

Eysenck (1991) as cited in Matthews et.al (2009) characterized the typical of introvert as someone who is quiet and retiring, is fond of books rather than people, is serious, keeps feelings under close control, is reliable and has high ethical standards.

To distinguish between feature of introversion and extroversion based on personal factor is that introversion tends to find the object orientation in inner while extroversion finds its orientation in the outside. Sharp (1987) pointed out that both introversion and extroversion are relative. Where the introverted judges the extraverted as shallow, lacking in inner depth while the extravert sees the introvert as unsociable, unable or unwilling to adapt to the real world. In conclusion, both introversion and introversion have its strengths and weaknesses although each has justification to one another. Sharp (1987) also pointed out that the introverted thinking type is oriented primarily by the subjective factor which focuses on concrete or abstract object, its motivation comes from within. Introverted thinking depends on neither immediate experience nor generally accepted, traditional ideas. Introverted thinking is concerned with the clarification of ideas, or even the mentation process itself, and only then (perhaps) with their practical application. 
In other words, introverted always think things over before doing anything.

\section{Extroversion-Introversion and Performance}

The question of which type of person is the better performer: an extravert or an introvert? Matthews et.al (2009) answered that it depends sometimes extraverts do better and sometimes introverts, depending on a whole range of task and contextual variables. Extraverts tend to show superior performance to introverts on some tasks, particularly relatively demanding tasks requiring divided attention, resistance to distraction or resistance to interference. Conversely, there are some tasks on which introverts perform better, such as vigilance and certain kinds of problem-solving. In conclusion, both extroverts and introverts have either strengths or weaknesses each other.

Nature of Speaking

\section{a. Definition of Speaking}

Speaking is a key to communication. By speaking, people can establish a good communication with others in daily life. Thornbury and Slade (2006) point out that this complexity derives from speaking being so ubiquitous in our daily language usage. It means that speaking is an activity that intertwined in daily interactions.

According to Brown (1994), speaking is an interactive process of constructing meaning that involves producing and receiving and processing information. It means that, we do speaking in order to give or gain information by understanding the meaning every single word by

the

speakers. 
b. Aspects of Speaking

There are some aspects that need to be considered when we are speaking English as foreign language.

\section{Pronunciation}

Some teachers of English as foreign language are challenged to be more realistically focused on clear and comprehensible pronunciation. At the beginning level, teachers expect learners to able to reduce their pronunciation errors from their ability to communicate. Then, at the advanced level, learners' pronunciation goal focus on their ability to enhance communication with use intonation features, phonetic distinction and take notice in their voice quality.

\section{Fluency and Accuracy}

The ability to speak is not only measured by having grammatical competence and semantic rules, but also we must be familiar with the knowledge of how native speakers use language in the context of well-organized interpersonal exchange, in which many factors interact. Thus, it became EFL learner's difficulties, especially adults, to speak fluent and appropriate with the target language (Richards \& Renandya, 2002, p. 216) as cited in Rahmana, et.al, 2016. In addition, Brown (2000:268) points out that the main focus of accuracy achievement is that the use of phonology, grammar and discourse appropriately while speaking. 


\section{METHODOLOGY}

Based on the objective of this study, the researcher applied a quantitative comparative study. The population of this study was the entire speaking I class in English Department of Halu Oleo University in academic year 2016/2017 which consists of two classes in total of 112 students. The sample of this study was chosen randomly of all the population by using Questionnaire of Eysenk Personality Inventory. The researcher sampled the four semester's students who were categorized as extroverted and introverted students using an instrument. The extroverted students which have been taken were 22 students, and the introverted students were 22 students. Two different instruments were used in this study. These included the final test score of speaking 1 subject aimed to know the students' achievement in speaking and Eysenck Personality Inventory questionnaire aimed to know students' personality. In analyzing the data, the researcher was used parametric statistic. There were two techniques in data analysis in this study, namely: descriptive statistics and inferential statistics used to examine hypothesis. The researcher used independent sample t-test to determine whether there is any significant difference between EFL extroverted and introverted students on their speaking achievement.

\section{FINDINGS AND DISCUSSIONS}

Findings

The data of students' personality which measured by questionnaire of Eysenck Personality Inventory shows in the following table: 
Table 4.1. : Students' Personality under questionnaire of Eysenck Personality Inventory

\begin{tabular}{|c|c|c|c|}
\hline Scores & Level of E and I & $\begin{array}{c}\text { Number of } \\
\text { Students }\end{array}$ & $\begin{array}{c}\text { Percentage } \\
(\%)\end{array}$ \\
\hline $0,1,2,3,4$ & $\begin{array}{c}\text { Extreme } \\
\text { Introvert }\end{array}$ & 1 & $1,14 \%$ \\
\hline $5,6,7,8,9$ & Fairly Introvert & 21 & $24,13 \%$ \\
\hline $10,11,12,13,14$ & Balance & 43 & $49,42 \%$ \\
\hline $15,16,17,18,19$ & Fairly Extrovert & 22 & $25,28 \%$ \\
\hline $20,21,22,23,24$ & $\begin{array}{c}\text { Extreme } \\
\text { Extrovert }\end{array}$ & 0 & $0 \%$ \\
\hline \multicolumn{2}{|c|}{ Total } & 87 students \\
\hline
\end{tabular}

The result of counting the questionnaire was 22 extroverted students and 22 introverted students. There are 43 other students were balance. In this research, students who have balance personality were eliminated.

The Data of Students' Speaking Achievement

The classification of Extroverted Students' Speaking achievement categorized based on the following:

Table 4.3. Classification of Extroverted Students' Speaking achievement

\begin{tabular}{|r|c|c|c|c|}
\hline No. & Categorization & Criteria & $\begin{array}{c}\text { Number of } \\
\text { students }\end{array}$ & $\begin{array}{c}\text { Percentage } \\
(\%)\end{array}$ \\
\hline 1 & Very Good & $86-100$ & 0 students & $0 \%$ \\
\hline 2 & Good & $75-85$ & 13 students & $59.09 \%$ \\
\hline
\end{tabular}




\begin{tabular}{|r|c|c|c|c|}
\hline 3 & Enough & $55-69$ & 9 students & $40.90 \%$ \\
\hline 4 & Less & $\leq 54$ & 0 students & $0 \%$ \\
\hline \multicolumn{2}{|l|}{ Total of Extroverted Students } \\
\hline
\end{tabular}

Based on the data presentation above, no one extroverted student categorized 'very good' and 'less' in their speaking achievement. There are 13 students categorized 'good' in speaking achievement with the percentage $59.09 \%$ and 9 students categorized 'enough' in speaking achievement with the percentage $40.90 \%$.

The classification of Introverted Students' Speaking achievement categorized based on the following:

Table 4.4. Classification of Introverted Students' Speaking achievement

\begin{tabular}{|r|c|c|c|c|}
\hline No. & Categorization & Criteria & $\begin{array}{c}\text { Number of } \\
\text { students }\end{array}$ & $\begin{array}{c}\text { Percentage } \\
(\%)\end{array}$ \\
\hline 1 & Very Good & $86-100$ & 0 students & $0 \%$ \\
\hline 2 & Good & $75-85$ & 15 students & $68.18 \%$ \\
\hline 3 & Enough & $55-69$ & 6 students & $27.27 \%$ \\
\hline 4 & Less & $\leq 54$ & 0 students & $0 \%$ \\
\hline \multicolumn{2}{|r|}{ Total of Extroverted Students } \\
\hline
\end{tabular}

Based on the table, no one the introverted student also categorized had 'very good' and 'less' in speaking achievement was 0 students. There are 15 students categorized 'good' in speaking achievement with the percentage $68.18 \%$ and 6 students categorized 'less' in speaking achievement with the percentage $27.27 \%$. The classification can be presented in the histogram as follows: 


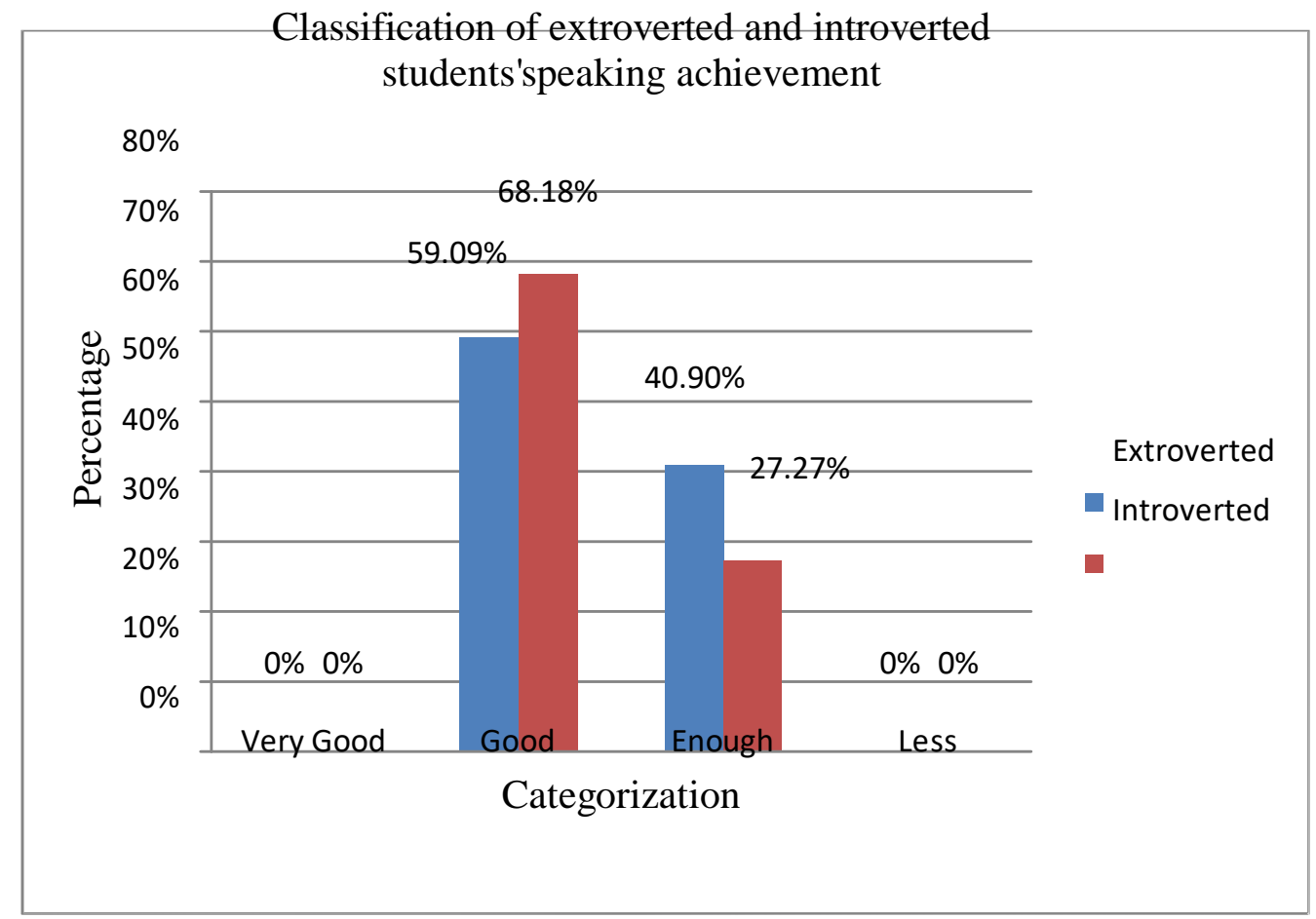

Figure 4.1. Classification of Extroverted and Introverted Students'speaking achievement

The histogram showed that in 'good' category the extroverted students' speaking achievement was lower than the introverted one. Meanwhile in 'enough' category the extroverted was higher than the introverted.

Descriptive Statistic

The descriptive statistics of extroverted and introverted students' score were analyzed by SPSS 16.0 windows. The result can be seen in the following table:

Table 4.5. Descriptive statistic of extroverted and introverted students' speaking achievement.

Descriptive Statistics 


\begin{tabular}{|c|c|c|c|c|c|c|}
\hline & $\mathrm{N}$ & Range & Minimum & Maximum & Mean & $\begin{array}{c}\text { Std. } \\
\text { Deviation }\end{array}$ \\
\hline $\begin{array}{c}\text { Extroverted } \\
\text { Introverted }\end{array}$ & 22 & 20.20 & 61.90 & 82.10 & 71.5091 & 5.08789 \\
$\begin{array}{c}\text { Valid N } \\
\text { (listwise) }\end{array}$ & 22 & 19.10 & 62.40 & 81.50 & 72.5182 & 4.79828 \\
\hline
\end{tabular}

The data explained about the differences value between extroverted and introverted students, where the mean of extroverted students was 71.50 and introverted students was 72.51. It showed that the value of extroverted students was lower than the introverted one.

Hypothesis Testing

The hypothesis testing used to investigate whether there was any significant difference between extroverted and introverted students' speaking achievement at speaking I class of English Education Department in Halu Oleo University academic year $2016 / 2017$ by using t-test with significant $(\alpha=0.05)$. The result of Independent Sample T-test can be seen on the table below:

Independent Samples Test

\begin{tabular}{|c|c|c|c|c|c|c|c|}
\hline \multicolumn{2}{|c|}{$\begin{array}{l}\text { Levene's } \\
\text { Test for } \\
\text { Equality of } \\
\text { Variances }\end{array}$} & \multicolumn{6}{|c|}{ t-test for Equality of Means } \\
\hline $\mathrm{F}$ & Sig. & $\mathrm{T}$ & df & $\begin{array}{l}\text { Sig. (2- } \\
\text { tailed) }\end{array}$ & $\begin{array}{l}\text { Mean } \\
\text { Differ } \\
\text { ence }\end{array}$ & $\begin{array}{l}\text { Std. } \\
\text { Error } \\
\text { Differ }\end{array}$ & $\begin{array}{c}95 \% \text { Confidence } \\
\text { Interval of the } \\
\text { Difference }\end{array}$ \\
\hline
\end{tabular}



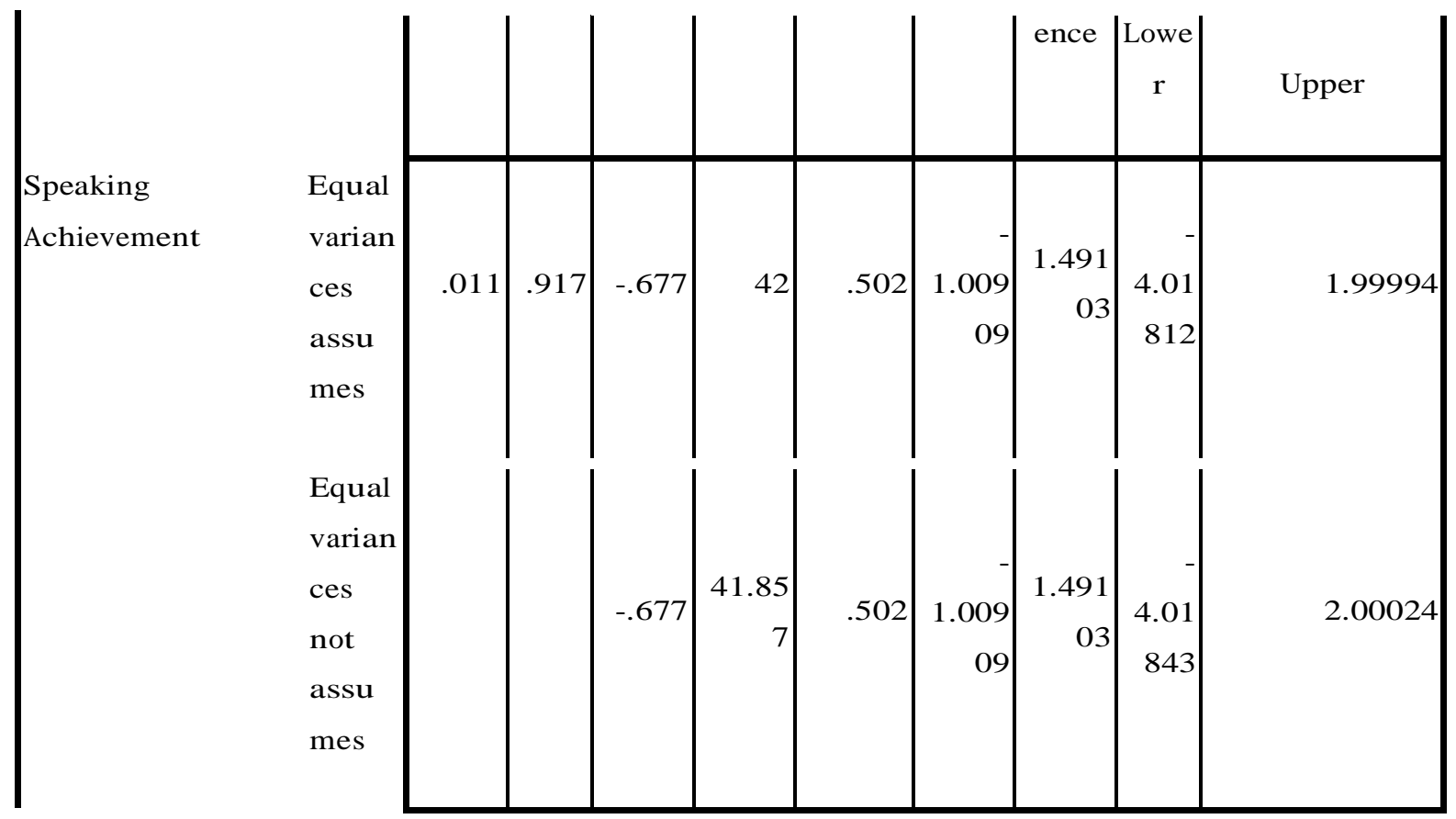

By putting those value into SPSS (Statistical Product and Service Solution) worksheet and analyze it by using Independent Sample T-test, it was gotten that the value of Sig.(2-tailed) $=0.502$ with $\alpha=0.05, \mathrm{H}_{0}$ was accepted and $\mathrm{H}_{1}$ was rejected. It is because of sig. (2-tailed) value is higher than $\alpha$ value. It means that there is no significant difference between extroverted and introverted students' speaking achievement at speaking I class of English Education Department in Halu Oleo University academic year 2016/2017.

\section{Discussions}

The result of this study showed that the introverted students got higher achievement in speaking I compared to the extroverted students, but there is no a significant difference between extroverted and introverted students toward their speaking achievement. The introverted students who tend to be quiet got better achievement in 
speaking I compared to the extroverted one. It might be due to the introverted students who preferring reading than socialize with other people, get input from reading activity itself. By reading, the readers allow to read repeatedly and absorb what have been read that can help the introverted to take intake what they've been read from books or journals. And this intake from reading can be source of their oral communication. This term, however associated with Ahmadian et.al (2011) that introverts learners tend to use more "conceptual" strategies to solve their communication problems. The finding of the study was contrary to the theory in introduction that according to Dewaele and Furhanm in the late 1990s synthesized convincing evidence from L1 studies showing that personality and speaking styles are related. Dewaele and Furnham point out L1 findings in psychology that extraverts have better short-term memory, extraverts are more impervious to stress and anxiety than introverts and speak more fluently than introverts.

\section{Conclusions}

After conducting the research at English Education Department in academic year 2016/2017 of Halu Oleo University and analyzing the data, it can be concluded that the extroverted students' speaking achievement is little lower than the introverted one. It means that the students personality, either extrovert or introvert do not give significant difference on the achievement of their speaking. Therefore, based on the research findings, personality factor did not affecting students' speaking achievement. There are no any better both extroverted and introverted students it terms of their speaking achievement. Both extroverted and introverted students have their 
own unique learning style or strategy where their unique learning style or strategy made them to find suitable and easy learning ways to learn speaking.

\section{REFERENCES}

Brown, H. D. (1994). Teaching by Principles: An Interactive Approach to Language Pedagogy. Englewood Cliffs: Prentice Hall Regents.

Brown, H. D. (2000). Teaching English by Principles: An Interactive Approach to Language Pedagogy (2nd ed.). San Fransisco, California: Prentice Hall Regents.

Busch, D. (2006). Introversion-extroversion and the EFL Proficiency of Japanese Students. Language Learning, 1(32), 109-132.

Dornyei, Z. (2005). The Psychology of the Language Learner Individual Differences in Second Language Acquisition. New Jersey: Lawrence Erlbaum Associates, Inc.

Matthews, G., Deary, I. J., \& Whiteman, M. C. (2009). Personality Traits (3rd ed.). Newyork: Cambridge University Press.

Rahmana, M., Rad, N. F., \& Bagheri, H. (2016). Developing EFL Learners' Speaking Ability, Accuracy, and Fluency. ELT VoicesInternational Journal for Teachers of English, 6(1), 1-7.

Richard, J. C. (2008). Teaching Listening and Speaking: From Theory to Practice. Newyork: Cambridge University Press.

Sharp, D. (1987). Personality Types : Jung's Model of Typology. Canada: Canadian Cataloguing in Publication Data.

Thronbury, S., \& Slade, D. (2006). Conversation: From Description to Pedagogy. Cambridge: Cambridge University Press.

Scientific journal is abstracted and developed further from the thesis written by the authors and the guidance supervisor thesis is Dr. Kamaluddin M.Pd and co-supervisor of thesis Siam, S,Pd., M.Ed. TESOL. 